\title{
Empowering the Social Economic Status of Higher Education Institution in Malaysia Through Waqf
} Fund

\author{
Sayuti Ab Ghani ${ }^{1}$, Rashid Nordin ${ }^{2}$, Burhanuddin Jalal ${ }^{3}$, Mohd Hamran Mohamad ${ }^{4}$, \\ Hj. Hasan Al-Banna Mohamed ${ }^{5}$, Mohd Mahzan Awang ${ }^{6}$ \& Abdul Razaq Ahmad ${ }^{7}$ \\ ${ }^{12345}$ National Defense University of Malaysia, MALAYSIA \\ ${ }^{67}$ The National University of Malaysia, MALAYSIA \\ E-mail: sayuti_70@yahoo.com
}

\begin{abstract}
Education waqf fund is one of the important and debated issues nowadays. The need for education waqf fund is critical during the uncertain times. The history and development of Islamic waqf have benefitted the Muslims by increasing the social economic status through the development of education. This research will focus on the development of education by using the waqf fund. The public universities in Malaysia have developed steps in strengthening education waqf by reducing dependence on government fund. In strengthening the research, writer try to clarify the mechanism that have been used by higher education system in Malaysia to increase the social economic status through waqf.
\end{abstract}

Keywords: Waqf, education, resource, distribution, financial

\section{Introduction}

Waqf practices in Malaysia is flourishing rapidly. Example of waqf practices given attention among the society is education, health, financing and defence waqf. In Malaysia during the early the early days, waqf is entirely being focused towards general and special waqf. However, along with the development of technology and changing time, there are various types of waqf offered in Malaysia. For example, general waqf, monetary waqf, share waqf, takaful and corporate waqf (Ainul Kauthar, et al., 2014). From this evidence, waqf practice will be able to be an important instrument in the Islamic society economic development in Malaysia. Besides waqf practice, other form of welfare property that is being used in the development of education is zakat and infaq. Waqf practices have been flourishing during the early days of Islam and have been developing rapidly especially in the education sector. The evidence is that a lot of education institutions establish during the time through the waqf concept, such as the building of mosque, school and universities. Waqf is not new in Islam, however it is developing following changes in time. The importance of developing the welfare fund such as waqf is relevant to the world. Due to the economic recession it also effects the development of education sector in Malaysia. Therefore, Malaysian government have directed all the government agencies to be thrifty in the management and administration including the Higher Education institutions. The public higher education institutions in Malaysia have been 
recommended to be independent especially regarding to university finance through focusing towards developing new finance resources for the universities through waqf fund. The implementation of waqf fund in public higher institutions is very crucial in view of the investment as the best alternative to reduce the burden of varsities in development and expenditure to benefit the students and staff. Eventhough the budget allocated for public universities in 2018 has increased to 13.15 percent that is from RM12.28 billion to RM13.89 billion (Berita Harian,7 November 2017), what is important in establishing and implementation of education waqf in public universities is that it can reduce the dependency of public universities to the government budget.

\section{Waqf Concept in Islam}

Waqaf or waqf is derived from Arabic words that is waqafayaqifu-waqfan meaning abstain. It can also mean to abstain or solitary confinement of something. Example waqaftu means I waqf (Ibn Qudamah, t.t). Waqf also being used with other words (1) al-Habs means to abstain. This narration is based upon the hadith that means "If you want it, waqf and donate the income "(Muslim,1348AD), (2) al-Man' means abstain or to freeze it (Al-Syarbini, 1377AD) and (3) Tasbil means gods will but from the translation is the same that is to abstain or transfer ownership (Wahbah, 1985). From Kamus Dewan, Waqaf means anything that is given and used by the public (as donation) or being allocated for the necessity that is related to Islam, such as building mosque or madrasah for public use. (Kamus Dewan,2000). Wahbah Al Zuhayli also clarify that waqf means preventing property that is permanent in nature, the benefit can be used for welfare as a way to be near to Allah SWT, property that is given as waqf to certain parties and they cannot have used the waqf arbitrary.

As a whole, waqf is one of the worships done by human being hoping for pleasure of Allah and for the sake of good human kind in the world and hereafter. According to the term of Islamic law, waqaf is understand as dedication of property, either as direct or innuendo, where property (substance) is detained/hold and only the benefit that is applied for the sake of welfare either in form of general or specialized use. Waqf concept is different from other public Islamic financial instrument example zakat, sedekah, hibah or etc. This is because waqf have certain special characteristic compared to another public Islamic financial instrument. This special characteristic can only be found in waqf that is abstinence and the concept of separation between ownership and right or the benefit of using it. The difference between waqf and other welfare deeds is that waqf is one type of giving property as absolute, whereby the property is stop from being sold and only the benefit can be used for public welfare and special purpose. In waqf implementation, there are four principles that had to be adhered in order that the waqf to valid. Waqf principle is; the giver and receiver of waqf, property that is being waqf and the narration or lafaz waqf.

\section{Education Waqf in Malaysia}

Waqf and education is not alien in Islam. Mosque is the first educational institutional waqf that happen during the Prophet Muhammad s.a.w. Quba mosque is established by Prophet Muhammad s.a.w when he arrived at Madinah in 622 A.D. followed by Nabawi mosque and other education waqf in the early decade of Islam (Mohd Affendi, 2011). Also, in Malaysia the development of education waqf is parallel with the development of education. Education starts within the religious institution such as surau, mosque and etc. There are various types of waqf practices and it develops from one generation to another. Apart from the physical form of school develop through the waqf concept there are waqf for student hostel, financial waqf and other types of such as for books, educational facilities and etc. Educational waqf institution is established or built using property that is donated by Muslims. Education is one of the ongoing activities comprised of elements of teaching, training, guiding and leadership focusing on transferring varieties discipline of knowledge, religious values, culture and skill that are valuable from one generation to another or from one individual to others that needs education.

Education waqf is the most significant to education institution. In Malaysia, education waqf have long been established through mosque, surau, madrasah and pondok by the locals and foreigner that immigrate to this country. Donations also come from the government and the rich in developing institutions based on Islamic education in this region (Siti Mashitoh, 2004). The pondok institution is one of the examples of the earliest waqf practice spearheaded by religious scholars in this country. Among madrasah and pondok that is built on the waqf land and finance by waqf fund are Madrasah Hamidiah (now known as Maktab Mahmud) in Kedah, Madrasah Sultan Zainal Abidin (now Unisza) in Terengganu and Kolej Islam Malaya (now Kolej Islam Sultan Alam Shah) in Selangor (Khoo,1980).Thus, looking at the success of the educational institutional, therefore this religious tradition should be continued. According to facts, the waqf 's donation in providing education to Muslims in this country are tremendous. It is given in various forms such as waqf for student hostel, scholarship, building and student facilities such as books, student tables and etc (Mohd Syakir et al., 2017)

Next, education waqf practices keep flourishing and develop the attention of the society and the government. 
There are several universities in Malaysia that are serious in developing the waqf concept as an engine to generate money for the universities such as Universiti Sains Malaysia and Universiti Malaya. The success evidence of the agenda of higher institutional waqf in Malaysia is through the development of the first waqf university that is University Islam Madinah in Cyberjaya which is the first university established under the Majlis Raja-raja Melayu on October 12, 2010. Madinah Islamic University (UIM) is considered the pioneer educational waqf in this country and become the guide in establishing higher education waqf in the future. In the era of globalization this challenge to develop the waqf should be taken by the educational institution to prepare the best education, efficient in every step of education for the whole society. The main challenge is to raise fund and the best way to increase the waqf fund so that waqf educational institute can leap forward for the sake of sustainability and continuity in education. Among the proposal to empower the educational waqf is to take advantage of the cash waqf concept to help to finance education through the subsidy mechanism to reduce fees or giving pocket money to the student. Universities are recommended to develop network with individual or well-known companies, together with foreign waqf foundation to raise fund (Mohd Syakir et al.,). Findings from research states that there is various source that can support the formation of educational waqf fund for public higher education institution (IPTA) in Malaysia. There are a lot of instrument that can be used to develop the waqf fund for (IPTA) in Malaysia. The common way waqf fund contribution is done in two ways that is removable and permanent waqf. All waqf funds are managed by the (IPTA) itself by depending on the university management and administration with the approval of State Islamic Religious Council in Malaysia.

\section{Challenges in Socioeconomic Development Through Waqf}

Socioeconomic development is one of the main goals of waqf worship in Islam. This development includes any activities that can meet the requirement of Islamic society. Waqf is proven to be the important asset in generating the economic prowess through the property donated by Muslims for the sake of welfare and development of Muslims and therefore indirectly towards the socioeconomics development in Malaysia as a whole. This is because it involves the sharing of property and benefits from the waqf property. Benefit from the waqf practice can develop property fund that kept increasing and develop consistently. Among property fund that can lead to socioeconomic development is through property waqf, cash waqf, equipment waqf and etc. Financing education through waqf instrument can reduce the drop out rate of the muslim children that cannot further their studies due to poverty. There are four factors determining the success of education waqf implementation are awareness of the society, demographic condition that is the Islamic population density, Muslim economic status and waqf administration and management that are competent and professional (Abdul Halim Sunny,2007).

One of the waqf practices submitted by Nik Mohd Azim (2014) that includes the socioeconomic development of Muslims is through the Waqf Monetary Fund (WMF) that is a social monetary fund that is establish through waqf instrument for the benefit of the society. Main objective of WMF is to accept deposit especially cash waqf from the depositors and become the financier for the economic social development of the Muslims. In reality, WMF act as a bank that is receiving deposit and disbursing to the deserving. WMF functions as a bank due to bank is a successful financial institution and effective in the role of receiving deposit and distributing economic fund to the related party. This is due to the fact that banking institutions are subject to strict audit and supervision also practicing effective corporate culture. From operational view, WMF will be operating like financial and other Islamic banking institution in this country. However, the main focus played by WMF is different from other available commercial bank or Islamic financial institution. Whereby WMF will managed the fund generated through the special instrument waqf as efficient as possible and use the fund to invest in developmental socioeconomic project that are productive and syariah compliant to maximize the benefit of ummah socio economic.

The role of education waqf cannot be denied because of the high potential impact in helping a country to generate sustainable education development. Among the goal of education waqf in higher education institution is to reduce the financial burden especially to underprivileged student to reach the vision and mission of the university. Below is the scope of main activities that can be implemented by the waqf unit in higher education institution (HEI).

a. Collection and receiving waqf.

b. Activities involving receiving, development and investing the syariah compliant waqf

c. Distributing the benefit of waqf to the beneficiary and other permissible purposes. There are ample source of waqf that could be introduce and implemented in HEI that are using the various concept of waqf and Islamic finance.

For example, Waqf HEI can introduce sources and waqf product as below: 
i. Cash waqf: waqf involving property in the form of cash.

ii. Share/Stock waqf: waqf involves selling unit of certain properties that is being waqf after that.

iii. Share waqf: selling of share waqf owned by the waqf owner

iv. Irsod waqf: waqf involving land from the government

v. Corporate waqf: waqf involving corporate or individual

vi. Financing from sukuk, crowd funding, ijarah financing and etc that are suitable

vii. Other sources that are syariah compliant (Siti Mashitoh et al.,2018)

The most important thing in determining the socioeconomic development is through distributing to the target group. Through this distribution, waqf property have gone through the phase of flow from one person to another in the form of the benefit of the property itself. Nooh (2006) have given his opinion that waqf property can be develop with various projects that can have impact on the Muslim economy directly or indirectly. Rent from the waqf building and other waqf project can be distributed for welfare and benefits of the Muslim. For example, by giving help to the needy under the asnaf tithe, donation for construction, management and mosque programme, surau, madrasah, clinic, hospital and etc. donation to a catastrophe, accident, medical treatment, orphanage, prison inmates, educational assistance, increasing the Islamic syiar dan assistance in development of the country and others that are related to the welfare and interest of Muslims. This is the true reality of the benefit of waqf distribution that include the welfare in development of human capital, whereby the concept of sharing the property wealth that is given by Allah SWT can be translated through waqf.

Besides that, the concept of waqf benefit distribution in education waqf in Malaysia in developing the socioeconomic can be seen in the (HEI). The distribution of waqf benefit in (HEI) only involve the target group that consists of needy students and staff. The concept of capacity to distribute the benefit of waqf is different between (HEI) in Malaysia depending to amount of waqf fund that can be collected by the (HEI) without the support of fund from the government. The concept of collecting waqf fund depends more on the marketing and promotion done by waqf center in every HEI itself. Maffuza and Noor Syahida (2014) proposed how waqf fund in (HEI) can be enhanced from time to time that is waqf model is not limited only in cash and property only; even to include teaching, research and publishing books and teaching aide. HEI is also recommended to establish special institute to manage waqf and increasing the asset and land bank donated by the government or individual through consultation. HEI is also recommended to develop network with individual or known corporate sector, apart from collaboration with overseas waqf foundation to collect fund. Waqf model in Al-Azhar University Egypt and Pesantren in Indonesia should be emaluated as a model in realizing the waqf educational institution that is well known in the world. Effort to develop understanding and enlightenment of the society is also important and should be implemented to ensure that the adequate fund can be achieved.

Najibah and Mohd Zamro (2014) proposed that to reinforce the development of education waqf is through strengthening of financial management that is the pillar to the success of an educational waqf institutions. Without adequate and consistent fund, any educational waqf institutions cannot operate successfully. Inconsistent source of fund can lead to various problems such as reduce in facility, limited human resource, limited promotional activities that leads to society not understanding the concept of educational waqf. Educational institutions especially HEI should not depend solely to grant and government assistance in managing the waqf operation. It is time for HEI to have its own fund and benefit the existence of various Islamic financial instruments in Malaysia today to generate income that can earn tremendous return to the waqf fund. Marketing aspects or waqf promotion is not less important during scholar's discussion. Ineffective promotion can lead to society knowledge about waqf cannot be updated, also it cannot correct the ill knowledge of society towards waqf.

\section{Conclusion}

On the whole, waqf is closely associated with educational institutions. History has shown that many educational institutions in Islamic history were developed through wakaf funds. Therefore, the government's step towards strengthening the education system in all educational institutions in Malaysia is one of the most effective steps in developing better and more effective education. All parties must play an important role in whether the government, the public and the individual play a role in developing educationbased educational institutions.

\section{References}

[1] Afendi. (2012). Peranan Institusi Keagamaan Dalam Membangun Ekonomi Ummah. Shah Alam, Selangor: Universiti Teknologi Mara.

[2] Ahmad Fatin Mohamad Suhaimi, Safura Ahmad Sabri Mohammad Aizham Mohammad Kassim, \& Hazlin 
Falina Rosli. (2017). Tahap Kefahaman Mengenai Wakaf: Kajian Kes di Selangor, Proceeding of the 4th International Conference on Management and Muamalah 2017 (ICoMM 2017). e-ISBN: 978-967-2122-15-9.

[3] Asykin. (2013). Potensi Wakaf Korporat kepada Pemilikan Ekuiti Muslim: Kajian di Wakaf An-Nur Corporation. Prosiding PERKEM VIII. Jilid 1. pp. 383396.

[4] Asmak Abd Rahman. (2009). Peranan wakaf dalam pembangunan ekonomi umat Islam dan aplikasinya di Malaysia. Shariah Journal, Vol 17, No.1, pp. 113-152

[5] Berita Harian Online. (2017). Bajet 'Soaring Upwards. 7 November 2017.

[6] Latiff Azha, Sayin Baharuddin, Sayurno, S.S. Salahuddin, M. Rani Afandi \& Hamid Afifah H. (2013). The Practice and Management of Waqf Education in Malaysia. Procedia - Social and Behavioral Sciences, 90: 22-30. https://doi.org/10.1016/j.sbspro.2013.07.061.

[7] Mahmood, R.H, S. Shahida \& Hameed, L.B. (2017). Kawalan Dalaman Tadbir Urus Wakaf di Malaysia. In Persidangan Kebangsaan Ekonomi Malaysia 2017, September (pp. 6-7).

[8] Mohamad, N. A., Kader, S. A., Zubaidah, S., \& Ali, Z. (2012). Waqf Lands and Challenges from the Legal Perspectives in Malaysia.

[9] Mohd Syakir Mohd Taib, Wan Kamal Mujani, Ermy Azziaty Rozali \& Kartini AbooTalib@Khalid (2017). Perkembangan Wakaf Pendidikan Tinggi di Malaysia, International Journal of West Asian Studies EISN: 21804788 Vol. 9, No. 1, (pp 82-92) DOI: 10.22583/ijwas.2017.09.01.07.

[10] Rabiatul Hasanah Mahmood Nazifah Mustaffha Latifa Bibi Musafar Hameed Norhanizah Johari. (2017). Pengurusan Wakaf Di Malaysia: Isu Dan Cabaran, Proceeding of the 4th International Conference on Management and Muamalah 2017 (ICoMM 2017). eISBN: 978-967-2122-15-9.

[11] Siti Mashitoh Mahamood, Asmak Ab Rahman \& Azizi Che Seman. (2018). Pembentukan Institusi Pengajian Tinggi Berteraskan Wakaf Di Malaysia: Cadangan Model Pelaksanaannya. Jurnal Syariah, Jil. 26, Bil. 1. pp. 1-22.

[12] Siti Mashitoh Mahamood. (2004). Peranan Harta AlSadaqah dalam Sistem Pendidikan: Pengalaman Sejarah Awal Islam Serta Penghayatannya dalam Perkembangan Institusi Pendidikan Kini. Kertas Kerja, Seminar Kebangsaan Peranan Harta Al-Sadaqah dalam Memartabatkan Pembangunan dan Pendidikan Ummah. Dewan Bestari, Intekma Resort, UiTM, Shah Alam. 14 Januari 2004. 